\title{
Existing Problems of Internal Control Auditing in Colleges and Universities and Its Countermeasures
}

\author{
Xianglin Sun \\ Henan Polytechnic University \\ Jiaozuo, China
}

\begin{abstract}
Through the analysis of existing problems of internal control auditing in colleges and universities, this paper puts forward the countermeasures in five aspects, namely, establishing clear goal, selecting appropriate mode, perfecting the content, choosing scientific process and method, building perfect operation mechanism for internal control auditing in colleges and universities. This paper aims to gradually promote the risk prevention level and management operation pattern of colleges and universities, so as to achieve the purpose of running a school.
\end{abstract}

Keywords-colleges and universities; internal control audit; problems; countermeasures

\section{INTRODUCTION}

The development of higher education career and its corresponding university management system are under the background of the reform of socialist market economic system and public finance. As legal entities for independent schooling, the financial resources of colleges and universities include fiscal appropriation, tuition fee, and other expenditures. The economic interests of colleges and universities have entered a new stage of diversification and multi-level financial work, which puts forward new requirements for the improvement of college and university's governance structure system and for the enhancement of the internal control of colleges and universities. Both the liberalized autonomy in running school and diverse economic activities require internal audit to play a more crucial role in the construction of the internal control system in colleges and universities, and make the internal audit of colleges and universities confront with severe test. The internal audit of colleges and universities plays an essential role in raising the management level and improving the risk prevention consciousness in colleges and universities. Therefore, all colleges and universities must establish and perfect the internal control audit system, and audit the soundness and effectiveness of the internal control of colleges and universities, so as to improve the internal control condition of colleges and universities, refine the internal control system of colleges and universities, raise the management level, strengthen their risk prevention capabilities and promote its sustainable development. Strengthening the ability of internal auditing has become a key means for colleges and universities to enhance their competitiveness, and the improvement of internal audit level should start from different levels and dimensions. At present, the internal audit of colleges and universities is experiencing transformation from the supervision and examination type department to management consulting type department, which aims to steadily enhance the risk prevention level and management operation mode in colleges and universities, and ultimately achieves the purpose of running a school. The foundation for the completion of this series of goals is to establish a sound and complete internal control management system and norms. An indispensable and critical step to promote the development of internal audit in colleges and universities is to improve the internal audit in the light of the internal control system.

\section{The MAIN PROBlems EXISTING IN CURRENT INTERNAL CONTROL AUDIT IN CHINA's COLLEGES AND UNIVERSITIES}

The internal control is a policy and procedure designed and implemented by the governance layer, management layer and other personnel for the purpose of ensuring the reliability of financial reports, the efficiency of operations, and the compliance with laws and regulations. It is an important means for the government departments and enterprises and institutions to carry out economic management activities.

Internal control audit is the audit behavior that the internal auditing staff test and evaluate the soundness and effectiveness of the organization's control environment, accounting systems and control procedures, find out control deficiencies and control weaknesses, and suggest improvements within the scope of certain authorization. It aims to examine and evaluate the legality, adequacy, effectiveness, and suitability of internal control.

The content of internal control mainly consists of five elements, namely, control environment, risk assessment, control activity, information and communication and internal supervision. Therefore, the content of the internal control audit is to test and evaluate the five elements that constitute the internal control.

In order to ensure the quality of internal control audit, internal audit is often required to follow certain procedures and adopt appropriate methods in conducting internal control audit. The internal control audit procedure can be divided into the audit preparation stage, the audit implementation stage and the audit report formation stage.

Chinese laws and regulations explicitly require colleges and universities to establish and improve the internal control audit system, that is to say, colleges and universities shall set up independent internal audit institutions and provide 
professional auditors to review various economic operations under the guidance of relevant guidelines and advice. However, at present, many colleges and universities neither attach importance to the construction and improvement of internal control system nor put emphasis on the audit of the internal control system, and do not establish relevant internal control audit system or have no perfect internal control audit system, specifically manifested as follows:

\section{A. Supervision Is Ineffective and the Internal Audit Function Has Not Been Fully Used}

The basic requirement for audit work is independence, but at present the internal auditing department in many colleges and universities lacks independence and has insufficient staffing. Although most colleges and universities have established independent internal audit organs in the light of Ministry of Education's Regulations for the Internal Auditing of the Educational System and Opinions of the Ministry of Education on Strengthening the Internal Auditing of Directlyaffiliated Colleges and Universities, the internal audit institutions of some colleges and universities are not independent, and some of them work with the discipline inspection department and supervisory department, even the financial department. The audit process is disturbed and restricted to a certain extent, and audit work is easily interfered by other institutions and personnel, and the ability to exercise authority legally is not strong. Meanwhile, due to insufficient understanding and emphasis on the internal audit work by the leaders in many colleges and universities, the internal audit work is difficult to carry out, and the independence is difficult to maintain in the process of auditing, investigating and dealing with the problems, and publicizing audit results according to law.

\section{B. The Audit Strength Is Insufficient}

With the continuous deepening of the reform of China's education system, the business activities of the universities themselves have also become increasingly complicated and diversified. The internal control audit of colleges and universities presents characteristics including multiple contents, high professionalism, and large span from the teaching management, scientific research management, human resource management, financial management, asset management to logistics management, which further increases the requirements for the number and professional ability of internal control auditors in colleges and universities. However, the actual situation is that the number of auditors is small and they also lack professional knowledge.

On the one hand, some colleges and universities even have the phenomenon that other department personnel take audit work as a part-time job. On the other hand, the internal audit employees in most colleges and universities mainly major in accounting, audit and finance, and the personnel having knowledge of teaching, research, finance, assets, procurement management, and related business link control are few, and the compound talents with the above knowledge and experience are fewer. Due to the insufficient auditing power, the unreasonable structure of auditors' knowledge and short of organizational governance, the internal audit department lacks the ability to undertake the increasingly diversified and complicated internal control audit of colleges and universities.

\section{The Auditing Field Is Incomprehensive}

Along with the fast development of higher education, the economic exchanges and the amount of fund are increasing, and the content and levels of internal management become diversified and complicated. This objectively requires that the colleges and universities must broaden the scope of internal control audits, shift the audit viewpoint and the starting point of problem analysis from specific economic business to the management process, take internal control audit as an important aspect of internal audit, and integrate the special audit including audit of financial revenues, economic responsibility audit during leading cadres' terms of office and construction work audit into the internal control audit. However, at present, the field of internal control audit in most universities is not comprehensive enough. The internal audit usually only emphasizes the internal control audit of financial appropriations, and weakens the audit of income-generating funds and other internal audit. During the actual implementation, the internal audit in most colleges and universities only puts most of the time and resources in the field of financial revenue and expenditure audit and focuses on the check of real account, the related records in account book and statement to prevent misstatement and fraud in the financial revenue and expenditure, but does not fully consider other areas of university management and administration. For example, they focus on auditing project budgets, and do not audit the bidding and tendering and hidden project acceptance, construction costs and other links from the perspective of contract audit. Besides, colleges and universities mainly emphasize the post audit based on financial revenue and expenditure, while ignoring the pre-audit and concurrent audit based on management audit and effectiveness audit, and cannot prevent it from happening.

\section{The Risk Management Audit Has Not Been Established}

With the rapid development of higher education, business activities in colleges and universities have become more and more abundant and the risks increasingly become complex. The common risks include:

1) Risk of excessive debt: Along with the continuous expansion of colleges and universities, the scale and the amount of capital income and expenditure of colleges and universities are also increasing. At present, some colleges and universities have not reasonably borrowed money combined with their own size and development situation, which results in excessive debt burden and even exceeds their own repayment ability, therefore, the universities fall into the risk of excessive debt.

2) Risk of investment failure: In recent years, colleges and universities have continuously expanded their scale, emphasized the service of society and increased foreign investment. However, the lack of awareness of risk management and foresee ability of changes in the external environment and complex economic operations has led to 
management lags in colleges and universities, and they fail to formulate corresponding business process procedures for certain new businesses in a timely manner. The failure of establishing internal financial risk control mechanisms that are fully adapted to the needs of the development of the market economy leads to a blind investment or erroneous investment, which results in the risk that the investment period is difficult to recover;

3) Risk of financial information distortion: Due to the imperfect internal accounting control system, there are problems such as out-of-control expenditures, the establishment of concealed accounts and imperfect internal check of accounting personnel division in colleges and universities, and there is a risk of financial information distortion.

4) Risk of corruption: Due to the imperfect internal control system in colleges and universities, problems including embezzlement and corruption have continued to arise in recent years, resulting in the loss of state assets. However, due to the fact that funding in colleges and universities mainly comes from financial allocations and student tuition fees and the source of funds is relatively stable, the leaders and teaching and administrative staff have a poor risk management consciousness, and most universities do not establish scientific and reasonable risk assessment mechanisms, let alone implement risk-oriented internal control audit.

\section{E. The Quality of Audit Reports Is Not High}

At the present stage, the quality of internal audit reports in colleges and universities is generally not high enough to achieve the desired results. Due to the lack of internal control evaluation standards, it is difficult for auditors to make accurate judgments on whether the internal control system of colleges and universities is sound and effective and to diagnose problems existing in internal control activities in the colleges and universities, so the quality of audit reports is not high; or because the assessment criteria for internal control in universities are not clear and specific, auditors tend to consider the thing as it stands and discuss it in a general way, therefore, accurate assessments are difficult to make. Or they do not make direct evaluations in audit reports. In this way, even if the internal control review is conducted, they will not be able to achieve the desired effect of the audit, making the quality of the audit report difficult to guarantee.

\section{COUNTERMEASURES TO IMPROVE THE INTERNAL CONTROL AUdiT IN COLLEGES AND UNIVERSITIES}

The basic functions of colleges and universities are education and teaching, scientific research, cultural heritage and social service. The operation objectives of universities are characterized by multi levels, policy-type, non-profit and pure education. Correspondingly, the internal control auditing operation in colleges and universities should also have its own characteristics, mainly as follows: First, the objectives and content of internal control auditing have multiple levels. The institutions in colleges and universities generally include various functional management departments, colleges, logistics departments, and school-run industries. The key points of internal control have different levels because of the different functions of the institutions. Second, the audit evaluation basis should be emphasized with policy compliance. Since the main sources of educational funds in colleges and universities are the state and the superior appropriation and it generally has specific uses, the internal control is to ensure the legal compliance of the use of funds, and policy should be emphasized in the audit evaluation. Third, the design of audit evaluation index should emphasize non-profit and pure education. The goal of colleges and universities is not to be profitable. The main goal of internal control is to optimize educational resources and prevent waste of resources. In designing universities' internal control evaluation indicators, special emphasis should be placed on non-profit and pure education.

The internal control audit system should include the following five aspects: establishing clear goal, selecting appropriate mode, perfecting the content, choosing scientific process and method, building perfect operation mechanism for internal control auditing in colleges and universities.

\section{A. Establish Clear Objectives of Internal Control Audit Incolleges and Universities}

The objective of internal control audit is different from that of the traditional internal audit in colleges and universities. It mainly aims at reviewing and evaluating the soundness and effectiveness of internal control systems in university's teaching management, scientific research management, financial management, asset management and procurement management, and lays more emphasis on reviewing and evaluating the comprehensiveness, integrity and effectiveness of the construction of internal control system in colleges and universities, as well as the compliance with the internal control system

\section{B. Select Appropriate Modes for Internal Control Audit in Colleges and Universities}

Due to the inconsistent degree of the development of internal control audit between major universities, there should be differences in the internal control audit mode applicable to various universities and universities and colleges should choose the audit model according to the actual situation of their own organization.

At present, the internal control audit modes available to universities and colleges include the comprehensive audit mode and the dynamic audit mode:

1) Comprehensive audit mode: The universities that have not yet established a complete internal control system and an internal control auditing system may select the comprehensive auditing mode. In the comprehensive audit mode, the auditors should combine the different internal control activities of each department and post to divide the internal control audit in colleges and universities into multiple types including teaching, scientific research, functional management, industry, and logistic services based on different types of businesses. 
For example, the college is engaged in teaching and scientific research activities, and its internal control should be conducive to the improvement of the quality level of teaching and scientific research; The logistics department mainly serves the "clothes, food, shelter and travel" of teachers and students, and its internal control should be to maintain the integrity and safety of the logistic assets and ensure the high quality and efficient service. Different types of business have different audit objectives and methods.

2) Dynamic audit mode: The universities that have comprehensively established internal control systems and have implemented the comprehensive audit of internal control may select dynamic audit mode. As the internal and external environments the universities that have comprehensively established the internal control system have confronted are constantly changing, the control risk coming along with it may also change. Therefore, for the purpose of ensuring completeness and effectiveness of the internal control system and strictly guarding against risks, it is necessary for universities to conduct regular dynamic consulting and auditing services that are mainly based on the audit department and supplemented by external experts.

\section{Perfect the Content of Internal Control Audit in Colleges and Universities}

Because of the unique characteristics of operation in colleges and universities, its internal control audit content should also have its specific connotation.

1) Control environment audit in colleges and universities: The control environment of colleges and universities is the sum of various factors that influence the establishment, enhancement and weakening of specific decision-making, procedures and efficiency of universities, and is the basis of internal control in colleges and universities. Its quality will directly determine the good and bad degree of implementation of the internal control audit in the university, so it is necessary for the university to audit the control environment.

The content of control environment audit should specifically includes: university administrators' theory on school management, value orientation and attitudes towards internal control; the rationality of division of internal organization structure and authority in colleges and universities; whether the economic activity decision-making bodies such as financial leadership group, the budget management committee and the charge management guide group have been set up; whether a sound financial management internal control system is established; whether the university has formulated a complete financial processing flow for various types of economic business; whether the software of accounting by EDP used in the university has been certified by the national authoritative department; whether the safety of various types of financial data can be guaranteed; whether the financial personnel has the required qualification for posting and received regular business training or follow-up education.
2) Risk management audit in colleges and universities: In the process of development, colleges and universities often face various risks such as fundraising, investment, capital security management and contracts, which will seriously threaten the sustainable development of colleges and universities. Therefore, colleges and universities should strengthen the risk management audit, attach importance to and enhance the work of risk management. The content of internal risk management audit in colleges and universities should include: whether the overall level of university or each department college establish a mechanism to identify risks, whether they can assess the possibility and impact of risk in a comprehensive and objective manner, whether they can take evasive, transfer or control actions to the identified risks, and whether the risk can be controlled within the acceptable range of the unit. For example, based on control objectives of the budget business, whether the relevant departments of the colleges and university have identified risks in the budget preparation, approval, execution and other links, whether they can reasonably evaluate them and take corresponding risk response measures; whether colleges and universities can accurately and timely identify and analyze, and effectively resolve the financial risks that may exist in the university.

3) Control activity audit in colleges and universities: The audit of internal control activities in colleges and universities refers that the auditors evaluate the rationality and effectiveness of internal control activities through the implementation of appropriate audit procedures and auditing methods. The audit of internal control activities in universities should include: review and evaluation of internal control of financial management, teaching management, scientific research management, material procurement, fixed asset management, fixed-assets management, construction work, economic contract management, etc.

4) Information and communication audit in colleges and universities: The content of internal information and communication audit in colleges and universities should include: record, report and release of major economic and business transactions, arrangement of project business content and budget allocation, information transmission and communication between financial and related business departments, transmission and communication of business information between departments, integration and sharing of network information resources, and safe and reliable financial and related business information systems.

5) Supervisionaudit of colleges and universities: Supervision and inspection is the process of monitoring, inspecting and assessing the integrity, rationality and effectiveness of its internal control by the unit to form a written report and make corresponding treatment. Therefore, the content of internal supervision audit in colleges and universities mainly includes: regularly audit and assess the organization's internal control activities, conduct internal audit and review for important departments such as finance, 
and form written opinions to report on the effectiveness of internal control.

\section{Select Scientific Internal Control Audit Procedures and Methods in Colleges and Universities}

Based on the theory of internal control audit and internal audit standards of our country, the internal control audit of colleges and universities should include pre-audit preparation stage, audit implementation stage and audit end stage.

1) The preparation stage of internal control audit in colleges and universities: In the preparation stage of internal control audit of colleges and universities, auditors should seriously carry out different forms of pre-audit investigation, figure out the overall situation of the organization, and prepare a scientific audit plan.

The preparation stage of internal control audit in colleges and universities mainly includes three links: the first is preaudit investigation and data collection. That is, internal auditors can choose the methods such as the use of previous audit information, conducting discussions with relevant personnel, field observation and certificate sampling to separately select representative and typical units in secondary school teaching units, functional management departments or economic entities, learn about business processes of colleges and universities from accounting control, asset management, internal revenue-generating and distribution, fund utilization, and internal management mechanisms, and master the key to control. The second is the establishment of internal control index system. According to the types of various departments, especially the content of economic activities, colleges and universities can determine the key items that should be paid attention to during the audit, and design the control points in the form of questionnaire, so as to form the internal control index system. The third is the formulation of internal control audit plan and audit work plan. On the basis of the data collected in the previous investigation, clear and detailed arrangements should be made in terms of project audit objectives, implementation steps, key control points and personnel division to prepare for the audit implementation stage.

2) The implementation stage of internal control audit in colleges and universities: Internal auditors should implement on-site internal control audit after they understand the status and operational procedures of the audited entity and formulate audit plans. At this stage, auditors should carry out substantive testing and conformance testing on the basis of the description and analysis of internal control to identify the control defects and their causes, forms of expression, and the degree of influence. The implementation stage of internal control audit in colleges and universities mainly includes three steps: First, taking the internal control index system formulated in the audit preparation stage as the standard, we will organize the audited unit to conduct self-evaluation work, and then the audit team will analyze the self-assessment of the unit to determine the scope and key points of substantive test in the next step. Second, conduct a substantive sample inspection. The auditors use the methods of extracting the certificate, inquiry, observation and drawing flow chart to verify the situation of unit's self-evaluation, and to master the strengths, weaknesses and existing defects of the internal control of the audited units. Third, prepare working papers. This step requires the auditors to sort and classify all the information and data learned during the audit implementation stage, and compile it as a working paper to form a preliminary evaluation of the internal control system.

3) The end stage of internal control audit in colleges and universities: At the end stage of internal control audit in colleges and universities, the auditors shall issue an audit report and provide audit conclusions, opinions, and suggestions on the soundness and effectiveness of internal control design and operation, and the identification and rectification of internal control deficiencies. Meanwhile, the objective of carrying out internal control audits is to improve the organization's internal management level and work efficiency. Therefore, at the end of the audit, the auditors should also pay attention to the communication with the audited units, point out the potential risks in terms of the weak points in its internal control, and put forward some suggestions for improvement to help the management set up sound and effective internal control.

\section{E. Establish Perfect Internal Control Auditing Operation Mechanism}

To achieve the effective operation of internal control auditing system in colleges and universities, the colleges and universities shall establish corresponding internal control auditing operation mechanism:

1) Set up independent and specialized internal control auditing institution: The internal control auditing is part of internal audit and its specific audit work shall be completed by internal audit department, therefore, the degree of specialization of internal auditing institution in colleges and universities just determines the degree of specialization of internal control auditing institution. However, as what mentioned before, there are some problems existing in the auditing institution in the colleges and universities, including lack of independence, insufficient audit strength, auditors without professional enough knowledge. Therefore, the colleges and universities shall attach full importance to the internal audit work, set up independent internal auditing institution, sufficiently protect the independence of internal auditing institution, establish internal control auditing institution under the auditing institution; the colleges and universities shall guarantee that the internal audit department can audit according to law, investigate and treat problems by the law, announce the audit results pursuant to the law and will not be interfered by other institutions and individuals; meanwhile, the colleges and universities shall equip professional auditors at full strength for the internal auditing institution, and strengthen the professional construction of the internal audit team: the leaders of internal audit department should have relevant professional knowledge and work 
experience; the internal auditors should have relevant professional background and professional qualifications.

2) Extend the scope of internal control auditing: The colleges and universities shall not only organize and carry out internal control auditing at unit level, but also conduct internal control auditing at business level, and shall rectify and reform the phenomenon that colleges and universities put more emphasis on real accounts, check between accounts, between accounts and tables, rather than auditing in other aspects. First, further strengthen the internal control auditing for funds management, pay attention to normalization, validity and compliance of the allocation of outsourcing expenditure, the grant of service fee, and scope and standard of expenditure range. Second, carry out the follow-up auditing in the whole process for the project approval, design, bidding, construction and completion of the major project. Finally, strengthen the asset management audit of colleges and universities. The assets management of the school-run enterprises is the weak link of the current state assets management in colleges and universities. It is the most important part of assets supervision, meanwhile, the most important part to strengthen assets management auditing of colleges and universities, and it is also the weak link of internal control auditing of colleges and universities. The internal control auditing aims to standardize the asset management of colleges and universities, improve the benefit of the use of assets and implement the management responsibility. With the help of internal control audit to promote the effective combination of asset management and budget management and financial management, prevent the loss of the school assets, especially the state-owned assets of the school run enterprises, and ensure the value added and increasing efficiency of the assets.

3) Standardize risk-oriented internal control audit procedures: With the continuous expansion of colleges and universities, colleges and universities have also become the areas where corruption cases occur frequently, which makes the responsibility and risk of internal audit in universities increasingly prominent. Therefore, it is imperative to carry out risk-oriented internal control audit. To carry out riskoriented auditing, it is necessary to pay attention to improving the overall quality of internal auditors and increase risk awareness; bring the auditing forward, focus on innovations in auditing means and methods, and accelerate the construction of audit informationization; attach importance to follow-up auditing, and implement the system of public audit results.

4) Establish and perfect the internal control audit evaluation criteria: Although some methods and standards have been established for the evaluation of internal control of enterprises, the internal control evaluation standards for nonprofit institutions such as colleges and universities have not been adequately studied. Therefore, it is difficult for auditors to make accurate evaluation when conducting internal control audit in colleges and universities, resulting in low quality of audit reports. Different internal control audit items in colleges and universities should have different evaluation criteria. The following three principles should be followed in the formulation of evaluation criteria for internal control audit in colleges and universities.

a) Objective-oriented principle: Internal control construction should serve the university's strategic objectives and business management objectives, so the indicators for evaluating internal controls should also serve these objectives.

b) Risk-oriented principle: The establishment of evaluation standards for internal control in universities should be forward-looking and should not be confined to the current situation of internal control; the future risks should be assessed through risk identification, and the relevant internal control evaluation criteria should be established.

c) The principle of combining qualitative assessment and quantitative evaluation: Qualitative assessment can be achieved through system construction and inspection of system compliance; quantitative evaluation can be achieved through spot checks of account books, field observations, supervision of counting, and substantive procedures.

With the continuous reform of China's college education system, the risks and competition pressures faced by colleges and universities in economic management will become larger and larger, and colleges and universities must do a good job of risk control. Therefore, strengthening internal control and risk management is an important task in the management of colleges and universities, and a perfect internal control audit system can help colleges and universities to deal with the risks. As a result, colleges and universities must take effective measures to strengthen internal control audit.

\section{CONCLUSION}

Colleges and universities must establish and perfect the internal control audit system, and audit the soundness and effectiveness of internal control of colleges and universities, so as to improve the internal control of colleges and universities, perfect the internal control system of colleges and universities, raise the management level of colleges and universities, enhance their risk prevention ability, and promote the sustainable development of colleges and universities. The objectives and contents of internal control audits are multilayered. The audit evaluation basis should emphasize the policy compliance, and the design of audit evaluation index should emphasize non-profit and pure education. The internal control audit should include five aspects: 1. establish clear objectives of internal control audit in colleges and universities; 2. select appropriate modes for internal control audit in colleges and universities; 3. improve internal control audit content in colleges and universities; 4. select scientific procedures and methods of internal control audit; 5. establish internal control audit operation mechanism.

\section{REFERENCES}

[1] Liu Fuli, 2014: Problems Existing in China's Internal Control Auditing and Countermeasures[J],Assets and Finances In Administration and Institution(1)P86-86. 
[2] Wang Licai. 2013: How Large and Medium-sized Enterprises Strengthen Internal Control Audit Work[J], Manager' Journal (26), P217-217.

[3] Zhou Lifeng. 2011: Preliminary Discussion on Conducting Internal Control Audit of Enterprises[J], Internal Auditing In China (2), P46-46.

[4] Yuan Rongqin, 2013: Problems Existing in Internal Audit of Colleges and Universitiesand Countermeasures[J], Internal Auditing In China (8), P27-27.

Wang Ni, 2011, Research on Problems and Countermeasures of Internal Control Audit in China's Enterprises[J], Money China (1), P306-306.

[5] Wang Li, Yang Zhonglian, Zhang Shuo, 2016: Research on Audit of Internal Control in Universities Based on Governance Perspective[J], Internal Auditing In China (10), P23-24.

[6] Xu Xiaoxiao, 2016: Internal ControlAudit and Prevention and Control of Clean Government Risks in Colleges and Universities[J], Studies of Finance and Accounting in Education (10), P81-82. 